\title{
Gendered Violence, Cultural OtheRness, AND HoNOUR CRIMES IN Canadian National Logics
}

\author{
DANA M. Olwan
}

Abstract. Honour-based violence, and the honour crime in particular, have assumed a central place in Canadian national discourse and consciousness. Understood within mainstream Canadian discourses as a uniquely dangerous form of violence, the honour crime has been linked to recent waves of migration and culturally specific notions of honour. Imagined as a foreign and imported phenomenon brought to Canada by immigrants who fail to assimilate to national and "western" ideals of gender equality, the crime is also viewed as an extreme form of violence that must be managed and ultimately expelled. Discourses surrounding the honour crime now inform various key social, racial, and cultural debates across national and transnational scales. By analyzing the discursive strategies used to construct and disseminate dominant discourses on honour killings, this article maps the heightened official state and public media interest in honour-based violence and crimes.

Keywords: honour crimes; gendered violence; race; media representations, Canada

Résumé. La violence basée sur l'honneur et le crime d'honneur en particulier, ont pris une place centrale dans le discours national canadien et dans la conscience canadienne même. Compris au sein des grands discours canadiens comme une forme unique et dangereuse de violence, le crime d'honneur a été lié à des récentes vagues de migration et des notions d'honneur précisément culturelles. Défini en tant que phénomène étranger et importé au Canada par les immigrants qui ne parviennent pas à assimiler les idéaux nationaux et "occidentaux" d'égali-

Acknowledgments. Many people helped me develop this article and I am thankful for all their support. Under the supervision and mentorship of Chandra Talpade Mohanty, research for this project was funded by a Future Minority Studies postdoctoral position I held in Spring 2011 at the Department of Women's and Gender Studies at Syracuse University. Special thanks go to Lisa Bhungalia, Carol Fadda-Conrey, Anne Grondin, Violette Humsi, Yasmin Jiwani, Shaista Patel, Sherene Razack, Robin Riley, Özlem Sensoy, Tamara Spira, and Sunera Thobani for their careful reading of earlier versions of this work. I thank the anonymous reviewers for their rigorous comments and I offer particular thanks to Augustine Park and Madeline Santos, the guest editors of this special issue, for their excellent feedback, patience, and generative critique of my work. 
té entre les sexes, le crime est aussi considéré comme une forme extrême de violence, qui doit être gérée et finalement éliminée. Ainsi, les discours qui entourent les crimes d'honneur à présent suscitent des divers débats sociaux, raciaux et culturelles au niveau national et transnational. En analysant les stratégies discursives utilisées pour construire et diffuser les discours dominants concernant les crimes d'honneur, cet article établit l'intérêt intensifié officiel et celui de la media publique au sujet de la violence et des crimes basés sur l'honneur.

Mots clés: crimes d'honneur; violence de genre; race; représentation de medias; Canada

In the early morning hours of June 30, 2009, the bodies of four womSen were discovered in a submerged car in the Rideau Canal in Kingston, Ontario. Shortly after, the Kingston Police released the names and ages of the victims to Canadian media and press. The four victims were identified as Zainab Shafia (age 19), Sahar Shafia (age 17), Geeti Shafia (age 13), and Rona Amir Mohammad (age 50). The three victims were biological sisters while the fourth victim, initially identified as the girls' aunt, was later determined to be the first wife of Mohammad Shafia. The women, reports explained, had drowned while driving to their home in a Montreal suburb from a trip in southern Ontario. Following a swift investigation, the Kingston Chief of Police, Stephen Tanner, ordered the arraignment and charging of Mohammed Shafia, Tooba Mohammad Yahya and Hamed Shafia with four counts of conspiracy to commit murder. On January 29, 2012, the Shafia trial — also known as the Canadian honour killing trial - ended with the jury finding all three guilty of four counts of first degree murder. In Canada, a first degree murder charge carries with it a life sentence, without possibility of parole for 25 years. It is the maximum sentence possible under Canadian law for a murder crime.

Drawing on the Shafia murders, and the national controversies it brought to the fore, this article maps what the honour crime label reveals about the national politics of race and racism in multicultural Canada today. It begins by providing a general definition of the honour crime as articulated by feminist scholars and international agencies, including the $\mathrm{UN}$ and Amnesty International. This work asks two interrelated questions: What ideas about racialized, gendered, and sexual violence does the honour killing label disseminate and construct in the Canadian context? How does the mobilization of the term shape national discourses and racial realities in Canada? This article examines the ways that major English-language Canadian dailies and Canadian state officials have deployed the honour crime discourse while shedding light on the various political projects and racial logics underpinning national investments in this crime. Drawing on what Lila Abu-Lughod (2011:26)describes as the "political work" of the honour crime, I examine how this crime was transported from a transnational and foreign geography to a domestic and racialized context of violence against women.

To address the mounting national interest in the honour crime, this paper turns to an analysis of the discursive strategies and political methods used to construct honour-based violence in state and popular discourses. I will argue that until 2001 the honour killings label mostly applied to crimes occurring outside of Canada. This focus on the foreign nature of these crimes helped bolster notions of cultural superiority and redraw the civilizational line between an inherently violent and barbaric Muslim east and a democratic, gender equal, and nonviolent secular west. I will then show that the decade after the $9 / 11$ attacks witnessed drastic shifts in public and national discourses surrounding the honour crime. While situating the discursive turn towards the honour crime in its historical context, this article charts its material consequences on racial and migrant others. In considering the increased visibility afforded to the honour crime and the stories it unfolds about gender and sexual violence, I explore what honour killings reveal about the interconnected logics of race and racism, multiculturalism, and nation building in Canadian society today.

\section{NARRATing Foreign Geographies of Violence}

Defined by various feminist scholars and international human rights organizations as the killing of a woman for the purposes of sexual control and social management, honour crimes are also "marked as a culturally specific form of violence, distinct from other widespread domestic or intimate partner violence, including the more familiar passion crime" (Abu Lughoud 2011:17). Honour crimes are described as the killing of a woman to recover wounded, damaged, or lost patriarchal honour. As Aisha Gill (2006:1) reminds us, "killing is not the only crime committed in the name of honour, but simply the most violent." Understood as a crime that is distinct in form and practice from other forms of gendered violence, international bodies like the United Nations Entity for Gender Equality and the Empowerment of Women (n.d.) describe honour related crimes as "violence stemming from a perception to safeguard family 'honour"" which includes "sexual, familial and social roles and expectations assigned to women and as prescribed by traditional ideology." In providing a definition of these crimes, Amnesty International (2012) states that "so-called honor killings are based on the deeply rooted belief that women are objects and commodities, not human beings entitled to dignity and rights equal to those of men." These definitions demonstrate that acts of gendered violence - and especially the honour crime - 
do not occur singularly but often go hand in hand with psychological and emotional harm, social and sexual control, and physical violence (Shalhoub-Kevorkian 2002). While the meanings of gendered violence that these definitions disseminate are not singular, they are collectively underpinned by an assumption of honour as a "predetermined concept," rooted in traditional cultures and ideologies (Grewal 2013:15).

Although the honour killing term has been used to describe certain eastern acts of violence against women (Abu Odeh 1997), the term has a relatively nascent history in Canadian mainstream and national parlance. In the immediate period before 2001, mainstream Canadian daily newspapers such as The Globe and Mail, the National Post, and the Toronto Star made frequent references to crimes known as "honour killings." Editorials covering these crimes focused mostly on their occurrence in Muslim states such as Pakistan, Turkey, Palestine, and Jordan. Invested in exposing the transnational aspect of these crimes, editorials often cited the United Nations Population Fund's (UNFPA's) widely circulated estimate that 5,000 women are murdered per year in honour related violence world-wide. Cleaved from a broader discussion of local manifestations of gendered and sexual violence, such quantitative evidence helps reify the idea that women in Canada live in relative safety, freed from the threat of violence. These works confirm the role that cultural geographers ascribe to media in constructing "a symbolic geography" of space and place (Mahtani 2009:258)

An article on honour killings in Pakistan by Meriel Beattie (1999), published in The Globe and Mail exemplifies this discursive style and politicized retelling:

Lahore - When Samia Imran walked up the stairs to her lawyer's office, it was in the hope of finalizing arrangements for a divorce.

When she came down, she was a corpse on a stretcher - shot through the head by a gunman who came to the office with Mrs. Imran's own mother and uncle. The killing has further inflamed a social and political debate about "honour killings" - when families kill a female relative considered to have shamed the household - even though Mrs. Imran's family members deny that they ordered her death.

The debate turns on the way Pakistani women are treated by the family and the state in a society where feudal power mixes with tribal customs and Islamic practice.

With a single word for her opening, the author transports her audiences to Lahore, Pakistan, where they become privy to the selective details of the life and death of Samia Imran. ${ }^{1}$ Her death, the author as-

1. Imran was Samia's married last name. Her birth name was Samia Sarwar. In media reports, she is referred to by either last name but most commonly as Samia Imran. serts, is a result of an "honour killing." Without providing much detail about the circumstances surrounding the crime, the author insinuates that Samia was punished for her desire to divorce her husband. The treatment of Pakistani women who live in a "feudal" society - as opposed to modern nation-states - is also briefly explored but only to signify the diminished capacities of the state when faced with a "society where feudal power mixes with tribal customs and Islamic practice" (Beattie 1999). Without discussing her position as a correspondent writing for a western daily, and without making clear her political investment in the details of this particular case, the author inserts Samia's death into a laden civilizational context where "modern, enlightened, secular peoples must protect themselves from pre-modern, religious peoples whose loyalty to tribe and community reign over their commitment to the rule of law" (Razack 2008:9-10).

Through this article and other media reports on foreign honour killings appearing in Canadian mainstream dailies immediately prior to 2001, the Canadian citizen becomes ideally situated to lament the fate of women from third world contexts (Cohn 1999; Farrukh 1999; Jehl 1999; Turgut 1998). ${ }^{2}$ Leaving unexplored the contexts of resistance to this example of gendered violence, readers are left to assume that violence against women remains largely accepted and unchallenged in Muslim majority states. Yet, as evidence from the local context of feminist organizing in Pakistan shows, Samia's murder became a rallying call for local feminist and human rights activists who pushed the state to take a tougher stance against state legislations that sanction violence against women (Hussain 2006). As Amina Jamal demonstrates in her work on feminist discursive practices and strategies in Pakistan, Samia's murder led to

a huge outcry in the country, especially over the failure of police to make any arrests and the hesitation of the state to provide security for human rights lawyers Asma Jahangir and Hina Jilani, who were threatened by supporters of Samia's family. (2005:73)

While the success of these campaigns has been limited, local evidence of activism and resistance trump dominant narratives of female victims, unsung individual feminist heroes, and overwhelming societal approval for the violation of women's lives - seductive narratives underpinning

2. As a search in the Canadian Newstand database reveals, there are numerous articles appearing in Canadian dailies focusing on the prevalence of this crime in foreign countries. Most of these articles discuss the social conditions, religious codes, and legal instruments that permit the murder of women in Middle Eastern, Arab, and Muslim countries. The articles by Cohn, Farrukh, Jehl, and Turgut are a very small sample of this journalistic trend. 
the stories circulated in many western editorials on the honour crime (Abu Lughod 2011).

While major Canadian newspapers make abundant references to "honour killings" taking place in third world countries, there is no discursive connection between these crimes and Canada prior to 2001. The first two government-level discussions of the honour crime appear to have taken place outside of Canada altogether. At a state dinner hosted by King Abdullah and Queen Rania of Jordan in 2000, Prime Minister Jean Chretien made his opinions on these crimes known to his hosts, saying that he "deplored" these crimes and wished they would be "taken out of the tradition, and make the law very clear" (quoted in Canadian Press). The law that Chretien was referring to is the much contested article 340 of the Jordanian penal code, a statute that some legal scholars argue "provides reductions of penalty for male perpetrators" when convicted of the crime of killing a wife, a daughter, or any "female ascendants or siblings [caught] with another in an unlawful bed" (Warrick 2005:326). Both Articles 340 and 98 are the subjects of intense internal debate in Jordan with various groups lobbying the monarchy and the government to strike these laws from the Jordanian Penal Code (Abu Hassan and Welchman 2005; Husseini 2009; Human Rights Watch 2009). Unsurprisingly, Chretien's comments on the honour crime reveal no awareness of Jordanian activists' efforts to challenge these discriminatory and dangerous bills.

Importantly, Chretien's remarks to the Jordanian monarchs duplicate the recommendations of various international bodies and organizations, including the 1979 Convention on the Elimination of All Forms of Discrimination Against Women (CEDAW), the Declaration on the Elimination of Violence Against Women of February 23, 1994, and UN Resolution 55/66, a resolution that identifies the obligation of all states to "prevent and eliminate crimes against women committed in the name of honour" (General Assembly 2001:3). In light of these international conventions, it is not surprising that the second reference to the honour crime by a Canadian state representative occurred in 2002 at a meeting at the UN. In a UN report on state progress on resolution 55/66, the Canadian representative made clear that honour related crimes remained "extremely rare in Canada" while asserting that they would be fully prosecuted under the Canadian Criminal Code (General Assembly 2002:3).

Confined to foreign geographies and viewed by Canadian state officials as rare local occurrences, why did honour killing discourse become so entrenched in the daily lexicon of Canadian state and media representatives in the past decade? What rhetorical and political ruptures caused the discursive and material turn towards the honour crime? In the next section, I address these questions by analyzing media responses to the Shafia murders. I will focus primarily on media responses relating to the Shafia murders and the trial that appear in mainstream Canadian print press, including three national newspapers: Toronto Star, The Globe and Mail, and the National Post.

\section{Domestic Horrors: Honour Killings in National Media NarRatives}

Canadian media plays a key role in disseminating ideas about immigration, belonging, and assimilation (Mahtani 2008; Jiwani 2006; Henry and Tator 2002). Building on the work of critical race scholars of media and communications, Minelle Mahtani argues that English-language media in Canada present racial minorities and new immigrants from racialized and minoritized groups "as threats to the nation-state ... linked invariably to crime and deviant patterns of behavior" (2008:640). In this context, representations of gendered and sexual violence occurring within racialized and immigrant communities are often both essentialized and culturalized (Razack 2003; Jiwani 2006; Volpp 2002). This section provides a textual analysis of a number of print media articles appearing in major English language Canadian dailies from 2009-2012. I located these articles by conducting a search of ProQuest Canadian Newsstand, a database containing texts of major newspaper dailies in Canada. While there were more than 3,500 articles printed on the topic of honour killings in Canadian newspapers in the three years between the murder and the trial, I focus on a small sample to highlight prevailing framings of the honour crime. ${ }^{3}$ Predominantly, these works established honour based violence as a foreign and imported phenomenon, driven by cultural and ethnic manifestations of murderous patriarchal honour. In analyzing the following articles, my aim is not to present a homogenous view of Canadian media or to overlook the few editorials that placed these crimes in a broader context of gendered and sexual violence (Jiwani and Hoodfar 2012; Kaplan 2010; Salutin 2012). Instead, I want to explore what the articles reveal about dominant Canadian national and racial anxieties, while showcasing how "rhetorical acts create contexts, project imagined publics, and establish communities" in tandem with historical events and occurrences (Hesford 2011:10).

To understand how the Shafia murders were first naturalized in Canadian media as a foreign, exceptional, and racialized occurrence, I will

3. Restricting the search in the same database to include only the terms "Shafia trial" and "honour killings" produces over 1300 articles. This is evidence of how widely discussed this trial was in Canadian society. 
turn to the press conference held in Kingston by Chief Stephen Tanner shortly after the arraignment of Mohammed and Hamid Shafia and Tooba Mohammad Yahya. This conference was crucial in popularizing a culturalized understanding of the murders. After calling a moment of silence for the victims of the murders, Tanner announced to various $\mathrm{Ca}$ nadian media representatives:

In our Canadian society, we value the cultural values of everyone that makes up this great country, and some us have different core beliefs, different family values, different set of rules.... Certainly, these individuals — in particular, the three teenagers - were Canadian teenagers who have all the freedom and rights of expression of all Canadians. (quoted in Proudfoot 2009)

... [They] all shared rights within our great country to live without fear, to enjoy safety and security, and to exercise freedom of choice and expression and yet had their lives cut short by members of their own family. (quoted in Chung and Dale 2009)

Tanner's assumption that the murders were motivated by a cultural and civilizational difference in "core values" and beliefs between Muslim Canadians and Canadian society is evident. He thus notes the collective deprivation of the women's right to life, a right enjoyed by Canadian citizens of all genders.

In his brief speech, Tanner appears moved by the loss of life and highlights in particular the murder of the three Canadian sisters. This focus on the three sisters resonated in Canadian media as well, especially as stories of the eldest sister's "rebellious" nature began to surface. Echoing the story of the young Aqsa Parvez, who, Canadian media argued, was killed for wanting to lead a "normal" life of a Canadian teenager, stories of Zaineb Shafia's desire for a Canadian life helped reify the assumption that the three sisters were killed because of the fundamental incongruity of Islam with modernity (Haque 2010; Zine 2009). Notably absent from Tanner's lament, however, was the adult female victim in the Shafia murders. As the first wife of a polygamous man, Rona Amir Mohammad's body cannot be represented in the same way as the bodies of innocent, young, and female Canadian teenagers because it is tainted by the "cultural differences" which Tanner considers to be the motive for murder. Rona's body cannot be used as an altar for Canadian ideals and cultural values because it had already broken them through its participation in the illegal practice of polygamy. In life, Rona's body accepts the conditions of polygamy, an affront to all women, and thus, in death, she cannot be contained within the heteronormative nuclear family ideal. Unable to recuperate Rona's body through the liberal feminist saviour trope, Tanner focuses his attention on the lost lives of young women, wanting the promise of a Canadian life. Tanner's statement, released shortly after the discovery of the crimes, raises the spectre of the honour crime, providing Canadian dailies license to present this act of violence against women as an exceptional occurrence.

Overwhelmingly, media responses to Tanner's speech were positive, affirming his assumption of the family's guilt and conceding the cultural divide argument he invoked. In The Globe and Mail, Ann Hui (2010) lauded Tanner for relieving Canadians of "the 'honour killing' taboo." Drawing on Wendy Brown's work on multicultural states, this "taboo" of honour killing can be understood as an example of tolerance at work. Brown writes that tolerance towards objects is a method of racial management and control and that "designated objects of tolerance are invariably marked as undesirable and marginal" (2006:28). The so-called lifting of the taboo on honour killings in Canada is an indication of a break with the discourse of tolerance and a failure of "tolerance ... to repress or override ... hostility or repugnance in the name of civility, peace, or progress" (Brown 2006:28). This failure to curb hostilities and disgus cannot simply be confined to an individual act or an independent breach in the Canadian discourse of civility. Rather, it reveals the fractures occurring in the veneer of multicultural civility surrounding discussions of honour related violence before September 11, 2001.

The various articles published in the Canadian press decrying the Shafia murders exemplify these breaks within Canadian multiculturalism. Published in the Toronto Star, Daniel Dale (2009) opens an article written shortly after the murders as follows:

We are shocked, naturally, when it is alleged that honour killings have occurred in Canada. They seem alien, inaccessible, at odds with everything we know about our country. How could a primitive thing like that happen in a progressive place like this?

As a representative of a monolithic and homogenous Canadian "we" that is "shocked" at the occurrence of "honour killings," Dale's question casts racialized acts of violence against women as existing outside of progressive and tolerant Canada. The crimes, at once declared "alien," "inaccessible," and "primitive," besmirch the myth of Canada's past and ongoing history of nonviolence and innocence. Dale explains that honour related killings are becoming more frequent in North America because "Liberal societies provide opportunities for social experimentation that may not exist in some immigrants' native lands."

Marked as crimes committed by immigrants whose cultures of honour lead to the murder of women, the honour crime also serves as a measure of Canadian attitudes towards issues of race, racism, and multi- 
culturalism. In an article from the National Post, Barbara Kay reminds readers that

Canadians are not racist, but they are increasingly skeptical about the ideal of multiculturalism. Mass immigration, many feel, will only be desirable when immigrants choose to Canadianize, as they did in the years before multiculturalism was ensconced as an official state doctrine in the 1970s. (Kay 2011)

In this work, Kay casts Canada as composed of immigrants who refuse its ideals and "Canadians" who are, by their very nature, "not racist" and who pride themselves on "multiculturalism ... as an official state doctrine." Unable to attract immigrants who freely choose to embrace Canadian ideals (or, in Kay's language, immigrants who "Canadianize"), multiculturalism has become a heavy burden, borne by Canadians who are "sicken[ed] and enrage[d]" by crimes against women. To appeal to Canadian society, and reconstitute its shaken belief in multiculturalism, "influential elites" and "our intelligentsia" must speak up against honour killings because "all such practices are anathema to Western culture, and in particular to our values of individualism and gender equality." In Kay's homogenous Canada, both the state and the people it represents are conceived of as a "singular entity, a moral, cultural and political essence, neutral of power, both in terms of antecedents and consequences" (Bannerji 2008:104). Through its appeal to a unified and powerful state, Kay's article makes the honour crime an aberrant act of violence, one that cannot be reconciled with the nation's values of individualism and its commitment to gender equality. Through such discursive delimitations, the honour crime is also fixed as a racial and national boundary, one that signifies the differences between real Canadians and conditional ones.

With few exceptions, the extensive coverage of the Shafia trial also replicated the same civilizational logic characterizing the first few weeks of discovery of the crimes. Because the judge presiding over the Shafia trial placed a publication ban on media preventing the reporting of evidence presented at the preliminary hearings, journalists who attended the trial such as Christie Blatchford of the National Post and the Toronto Star's Rosie DiManno gained particular importance in shaping public understanding of the murders. As an indication of the popularity of her work on the trial, Blatchford's articles have also been collected in an e-book entitled Killed because They were Girls: The Complete Coverage of the Shafia Trials (2012). In her various court reports, Blatchford reminded readers that the Shafia sisters lived under the power of a patriarchal, temperamental, and violent man. Their household was governed by lies that were perhaps sanctioned by the religion, language, and culture from which they hailed (Blatchford 2012). Canadian dailies thus perpetuated the idea that the Shafias were culturally other and their familial relationships were inherently premodern. In describing their family arrangements, for example, Blatchford routinely referred to the Shafias as a "sprawling clan," reinforcing the assumption that the Shafias were unusual, foreign, and even primitive (2012).

Expressing her anger and frustration at the murders, Rosie DiManno (2011) asserted that the murders were an atrocious tragedy that was "spawned by punitive cultural traditions transplanted to Canada." She wrote,

There's a reason why the Justice Lady is blindfolded. It depicts objectivity - fairness and equality for all before the law. A disregarded concept in Afghanistan; a core value in the Canadian court system. Let us state the obvious: Canada isn't Afghanistan. That culture is not our culture and their attitudes towards females are totally alien to ours.

Central to the national hierarchy reproduced in DiManno's work is a belief in the egalitarian conception and application of the law. While Afghanistan is seen as a place of inequality and lawlessness, Canadian courts are imagined as spaces of objectivity where notions of "fairness and equality for all" guarantee justice for victims. What remains absent from this representation is recognition of how the legacies of genocide and colonialism have shaped the operations of the law against victims of gender and sexual violence. As scholars have shown, legal justice remains a difficult feat for indigenous women and racial others in the Canadian state (Razack 1998, 2012; Fournier et al. 2012). Contesting the trial of serial murderer Robert Pickton and the state inquiry that followed, indigenous groups fighting for justice for missing and murdered Native women have shown how the law and the courts are complicit in concealing and enabling violence against indigenous women. While DiManno's work continues to gain mass circulation, stories that trouble legal and cultural innocence remain absent from her analysis. At their core, racialized and indigenous people's encounters with Canadian courts dislodge assumptions of national, racial, and moral superiority and innocence - assumptions that buttress the popularity of the writing of DiManno and others on the Shafia trial in particular and the honour crime in general.

What do such framings suggest? How do they reproduce civilizational thinking and reinforce the borders of the nation-state? What roles do they play in both representing and creating the reality of differential belonging for racialized others in multicultural Canada? What do they 
tell us about the status of Canadian national belonging and unbelonging? In what follows, I will address these questions by turning to a discussion of the Conservative government's federal efforts to utilize honour based violence into a long-term strategy of racial management, boundary marking, and state control.

\section{Discover Canada: No Barbarians Allowed}

In her work on honour killings in American and Indian media, Inderpal Grewal asserts that "a broad array of technologies of governance have come into existence in response to honour killings" (2013:8). Sustained by racial and national anxieties, the honour killing discourse both narrates a form of gendered violence and (re)produces particular tools of governance and control, including the strategy of protecting and saving women from certain forms of patriarchal violence (Grewal 2013). In examining the state's discussion of the honour crime, this section explores what its stance means for racial others and migrants in Canada. Here I focus on both the Canadian citizenship guide and a number of statements made by the former Status of Women Canada minister, Rona Ambrose, because of their formative role in displaying and constructing honour crime discourse at the national level. As minister, Rona Ambrose held the highest position of authority in the government (after the Prime Minister) on issues relating to women. She also commanded a large budget that is now being used to fund projects on the honour crime. This section analyzes Ambrose's stance on honour crimes in relation to Canada's officially stated position on gender and sexual violence as exemplified in Discover Canada: The Rights and Responsibilities of Citizenship. While this document has received much consideration from scholars (Blake 2013; Jafri 2012; McKay and Swift 2012), its study is warranted because "such guides are among the most widely circulated statements about Canada's past and present ever published" (McKay and Swift 2012:15). As a document that is used to test whether new immigrants qualify for Canadian citizenship, attention to the guide's politics reveals the regulatory powers of categories like gender equality, human rights, and the law.

Published in 2009, the 62 page document makes explicit the obligations of immigrants to Canada. Offering a version of citizenship contingent upon performances of loyalty oaths to the Queen of England, meaningful service to the Canadian state, and respect for the freedoms of others, the document sets forth a relationship between immigrants and the state predicated on immigrants' willingness to obey Canadian values, customs, and laws. Further, the new immigration guide makes clear Can- ada's commitment to "the equality of men and women" but goes even further to state the following:

In Canada, men and women are equal under the law. Canada's openness and generosity do not extend to barbaric cultural practices that tolerate spousal abuse, "honour killings," female genital mutilation or other gender-based violence. Those guilty of these crimes are severely punished under Canadian criminal laws. (2009:9)

This note to citizenship hopefuls sets up the state as the authority on moral and legal behaviour and societal practices. In addition to explicitly naming "barbaric" practices such as honour crimes, the document also defines what constitutes "equality between men and women." Here, the state becomes a barometer for acts of violence against women that contradict Canada's tradition of "openness and generosity."

Cloaked in feminist language, the citizenship guide reveals Canada's thinly veiled disdain for new cultural, religious, and racial others whoin spite of the state's precarious and conditional approval - are always configured outside of its bounty and good favour. Perhaps unsurprisingly, the emphasis on the "equal" status of men and women in Canada in this document contradicts the Conservative government's elimination of equality from its national priorities. As Sedef Arat-Koç (2012:8) reminds us, the drastic cutting of funding of Status of Women was also accompanied with the demand that it remove "equality" from its stated mandates and goals. Under this Conservative vision, equality between men and women "had already been achieved in Canada" and was therefore no longer "a government priority." If we are to accept that equality was no longer a national government concern, why was it being emphasized in a document that introduces Canada to new immigrants? What gender and racial regimes does such an inclusion enshrine?

The Citizenship and Immigration Guide tells the story of a nation functioning through the logic of preemptive strikes - attacks launched to conceal the deep racial, economic, and national schisms unfolding within Canadian society. This conservative vision of nationality evidenced in the guide showcases how, as victims of gendered violence, whether dead or alive, the bodies of some women are useful for what Jasbir Puar (2007:2) calls "the successful management of life." The castigating role the guide performs demonstrates the precariousness of recognition and belonging for racialized others. Through the assumption of their susceptibility to certain forms of cultural and gendered violence, Muslim women's bodies not only mark the ideological and political boundaries of the nation state but also enable its governing functions. Through death, Muslim women acquire special status because their dead 
bodies can be used to script visions of gender equality to which the Canadian state, under the Harper regime, neither adheres to, nor financially or politically endorses.

On July 12, 2010, then Minister of Status of Women Canada, Rona Ambrose, utilized the same logic of preemptive strike to declare the government's stance against the honour crime. Speaking to a gathering of journalists and community members at the Punjabi Community Centre in Mississauga, Ontario, Ambrose condemned honour related violence against women, making clear that such crimes have no place in Canadian society and that their perpetrators would be prosecuted to the full extent of the law. Arguing against the appeal to culturally relativist positions and ideas, the minister proclaimed Canada a nation vehemently opposed to violence against women and asserted the state's commitment to the human rights and dignity of all persons.

Labelling the honour crime a "serious problem" plaguing Canada, Ambrose went on to denounce the murder of family members:

People come to this country to enjoy and embrace the values and opportunities that Canada provides, and as a nation we are proud of the contributions made by our diverse cultural communities... However, killing or mutilating anyone, least of all a family member, is utterly unacceptable under all circumstances and will be prosecuted to the full extent of the law. (Status of Women Canada 2010a)

By focusing on immigrant victims who have arrived in Canada "to embrace the values and opportunities that Canada provides," Ambrose makes gendered violence appear exceptional, placing it squarely in the daily practices of Canada's cultural others. The juxtaposition between good immigrants who make contributions to Canada and bad ones who kill and mutilate is stark and makes a connection between cultural practices and acts of gendered and sexual violence. In this way, Ambrose can render fact the speculative charge of cultural violence without questioning the cultural basis of gendered violence in Canadian society at large. Of course, this is neither a new or particularly original strategy. Its power to inscribe Canadian national superiority and underwrite the cultural inferiority of Canada's racial others cannot be underestimated, however.

Writing on the culturalization of violence against women, Leti Volpp (2002:394) reminds us that "many feminists and battered women's advocates suspect that 'other' cultures actually support domestic violence - without turning to ask whether this may also be true in their own communities." This concealment of broader occurrences and contexts of violence is useful and productive for racially dominant groups and racial states. According to this logic, it is not only that inferior cultures produce violence but also that inferior peoples and states sanction them. In Ambrose's speech, Canada is cast as a country of opportunity, a welcoming and safe home that is distinctively superior to "places around the world where violence against women is formally endorsed and employed" (Status of Women Canada 2010b). Popular narratives of such stature, while enduring, are repeatedly being replenished through the state's exclusive focus on the honour crime.

Significantly, Minister Rona Ambrose's speech was inspired by the publication of Aruna Papp's (2010) study: "Culturally-driven violence against women: A growing problem in Canada's immigrant communities." Sponsored by a conservative think tank called Frontier Centre, Papp's report asserts that domestic violence against women in Canada occurs at a frequent rate in the homes of immigrants, especially those who hail from developing countries. In her report, Papp states:

While violence against women is deplored in general in Canada, few researchers appreciate the many distinctions between historically observed Western patterns of abuse of women by men (and abuse of men by women) and newer, culturally driven abuse of girls and women by both men and women (with virtually no abuse of men by women in such culturally induced situations). (2010:4; emphasis in original)

Resting on the false premise that acts of violence against women in Canada are "deplored in general," Papp's logic of distinction coheres differences between "Western patterns of abuse" and other forms of "culturally" induced forms of violence. Papp's critique rests on a disavowal of Canadian multiculturalism, a policy that she feels has prevented the public and "well-meaning advocates for female equality" from addressing honour killings as a distinct crime occurring in immigrant homes for fear of "racializing" and thus demonizing entire ethnic communities (2010:4). In Papp's study, the failures of multiculturalism are not simply caused by its own weaknesses, but also produced by "South Asian immigrants" and "community leaders" who "consciously exploit multiculturalism-inspired fears amongst mainstream Canadians of appearing racist or of perpetuating cultural stereotypes" (2010:8). Papp concludes her work with recommendations that the Canadian government provide mandatory gender equality training for immigration applicants.

Since the publication of this report, Papp has emerged as a leader in the fight against gendered and sexual violence and the honour crime. Seen as an expert for her role in founding the South Asian Family Services (now known as South Asian Settlement Services), a nonprofit organization with charitable status, Papp is also a cultural expert who provides personal insights bolstered by experiential evidence to support her views 
on violence. As a survivor of gendered violence, Papp has spoken at conferences like "Dying to be Canadian: Honour killings in Canada" where members of the Vancouver Police Department learned how to identify honour crimes without falling into the trap of cultural relativism. ${ }^{4}$ In addition, Papp's recently published memoir, co-authored with Barbara Kay of the National Post, sheds light on "what it is like to grow up in a family schooled in honour-based culture" (2011:v). This memoir was launched at an event attended by Rona Ambrose who, in a statement released by Status of Women Canada, lauded Papp for "bearing courageous witness to the terrors of violence committed in the name of "honour" " and for confronting the "barbaric practices associated with 'honour' motivated violence" (Status of Women Canada 2012).

As a racialized expert on gender violence in eastern cultures and contexts, Papp shields government-sponsored interest in honour killings from the charge of racism. In effect, her media appearances and expert trainings narrate violence and oppression without explicating "the institutional context within which 'oppression' becomes meaningful" (Lazreg 2009:34). The pitfall of this narrative strategy is that it ends up denying the contextual specificities necessary to better understand and combat gendered violence (Razack 2003, 2008). Instead, through an insistence on voice, authenticity, and experience, honour killings are placed into a field in which national benevolence, feminist credentials, and human rights are displayed and asserted in interconnected and deeply problematic ways (Hesford 2011).

The unabashed collaboration between an openly conservative think tank, a partisan expert, and the government is not surprising when understood in light of what Ian McKay and Jamie Swift view as a carefully considered strategy for rebranding Canada by a government that increasingly "comports itself like an authoritarian regime" (2012:12). As McKay and Swift show in their work, the contemporary historical moment makes feminist allies of the most unlikely suspects (2012:273). While the historical significance of these events is still unfolding, they demonstrate the nation's investment in a selective account of the epidemic of violence against women. In its different announcements and initiatives that target a version of violence cleaved from the broader continuum of violence against women, the Canadian government shows that the bodies of dead Muslim women killed by Muslim men can be used to strengthen exclusionary narratives of national belonging. In fact, it is

4. This conference was held in 2012. Papp has also provided training for the Calgary police, Niagara Regional Police, and York Regional Police. On her website www.preventhonorbasedviolence.com, Papp advertises workshops on "harmful cultural practices," "risk assessment," and "forced marriage vs. arranged marriage." In 2013, Papp also served as a "Canadian delegate" to the United Nations (see "Training Delivered"). on the murdered bodies of Muslim women that myths of national and cultural superiority and racial and historical innocence are repeatedly inscribed. It is precisely this narrative that allows the Canadian nation state to commit over $\$ 2.8$ million dollars to community projects targeting honour related violence while simultaneously stripping Native women's associations from funding crucial for their work. The 2010 defunding of Sisters of Spirit, an organization that has dedicated its energies to exposing and ending violence against Native women, is one example of the ostensibly contradictory discourses at work in the intensified focus on the honour crime. As Sedef Arat-Koç notes, the "key to this seeming paradox is that the hyper-visibility of 'other' women helps normalize and naturalize the gender order in the larger society" (2012:9; emphasis in original). Through their focus on the honour crime, Canadian state officials perpetuate a national order that willfully ignores evidence of violence, sexism, and inequity in Canadian society at large. This historical moment, rather than advancing the cause of women or securing their rights, often fractures their communities and undercuts the possibility of feminist solidarities.

\section{Conclusion}

In recounting events leading up to the Shafia trial, this article has attempted to show how the mobilization of honour killing discourse has shaped media representations of gendered crimes of violence and the practices of the Canadian state. Examined through the lens of race, I have argued that the interplay between media and state focus on the honour killing label delimits the lives of racialized Canadians. In reading media and state responses to the honour crime, I have shown how the discourse codified acts of gendered violence in ways that targeted racialized communities. This paper argued that the selective focus on honour crimes has inspired "culturalist (and racist) discourses and policy approaches" that hide systemic and institutionalized forms of violence, including the violence of racism (Arat-Koç 2012:9).

To understand why the honour crime occupies a central place in national discourses, one needs to place this heightened interest in a historical context in which the bodies of dead Muslim women are used to assert national superiority and extend techniques of border management and control (Thobani 2007). Rather than view these mobilizations primarily at the discursive or affective levels, I argue that the selective state interest in acts of gendered violence has already charted a new Canadian racial landscape that is most clearly evidenced in migration policies and 
practices. In 2011, for example, the Toronto Star reported a 25 percent decrease in the number of immigrants admitted to Canada in the first quarter of the year (Keung 2011). This measure has been accompanied by the increased shift from permanent settlement to precarious and temporary belonging. As migration justice groups have shown, the Conservative government has adopted harsher family reunification measures, and introduced a two-year "conditional" permanent resident status for the sponsored partners and spouses of immigrants and Canadian citizens. Under the guise of fiscal responsibility, the government has also cut federal health refugee programs and lowered the salaries of temporary migrant workers (Star editorials 2011; Cohen 2012; Keung 2012). Together these migration policies do not simply usher new or unusually precarious forms of belonging but enshrine, instead, racial differences at the national level.

How do the dominant media and state inscriptions of the honour crime inform, rather than simply reflect, Canadian national logics? What are the material consequences of the honour killing label on racialized Canadians? And how might we enact a radical antiracist feminism that does not reproduce an exclusionary and dangerous nationalism? Efforts to confront gendered and sexual violence under the rubric of honour killings buttress the claim of the crime's rise and singularity. Without attention to the larger contexts of gendered and sexual violence, they can play a dangerous role in furthering exclusionary politics and realities. Powerfully wielded by state officials and dominant media, the current manifestations of the honour killing discourse conceal — rather than disrupt - the conditions that reproduce gendered violence within $\mathrm{Ca}$ nadian society. This includes the violence of migration and the unresolved tensions of citizenship. My concern with honour killing discourse is not simply the condemnation of state or media practices. Instead, I am invested in thinking about the possibilities of feminist solidarity and alliance in combating gendered violence. Envisioning radical feminist solidarities against the intricacies and intersectionalities of gendered violence requires challenging the exclusionary and dangerous contours of Canadian national logics.

\section{REFERENCES}

Abu Lughod, Lila. 2011. Seductions of the 'honour crime.' Differences 22(1):1763.

Abu Hassan, Reem and Lynn Welchman. 2005. Changing the rules? Developments on 'crimes of honour' in Jordan. Pp. 199-208 in Lynn Welchman and Sarah Hossain, eds., 'Honour': Crimes, Paradigms, and Violence against Women. London: Zed Books.

Abu Odeh, Lama. 1997. Comparatively speaking: The 'honor' of the 'East' and the 'passion' of the 'West.' Utah Law Review 20(2):287-307.

Amnesty International. 2012. Cultures of discrimination: A fact sheet on 'honour' killings. www.amnestyusa.org/sites/.../honor killings fact sheet final_2012.do. Accessed 26 May 2013.

Arat-Koc, Sedef. 2012. Invisibilized, individualized, and culturalized: Paradoxical invisibility and hyper-invisibility of gender in policy making and policy discourse in neoliberal Canada. Canadian Woman Studies 29(3):6-17.

Bannerji, Himani. 2008. The Dark Side of the Nation: Essays on Multiculturalism, Nationalism and Gender. Toronto: Toronto Scholar's Press.

Beattie, Meriel. 1999. Honour killings continue to punish Pakistani women. Globe and Mail. Toronto, June 3:A13.

Blake, Raymond B. 2013. A new Canadian dynamism? From multiculturalism and diversity to history and core values. British Journal of Canadian Studies 26(1):79-103.

Blatchford, Christie. 2012. No honour in cold-blooded, shameless murder of Shafia girls. National Post. http://fullcomment.nationalpost.com/2012/01/29/ jury-reaches-verdict-in-shafia-trial/. Accessed 25 July 2010.

Blatchford, Christie and the National Post. 2012. Killed Because they were Girls: The Complete Coverage of the Shafia Trials. Ottawa: National Post.

Brown, Wendy. 2006. Regulating Aversion: Tolerance in the Age of Identity and Empire. Princeton, NJ: Princeton University Press.

Canadian Press. 2000. Chretien echoes call for eliminating honour killings in Jordan. Canadian News Wire. Toronto. April 16: np.

Chung, Andrew and Daniel Dale. 2009. Were deaths of 4 Women a matter of 'honour'? Toronto Star. http://www.thestar.com/news/ontario/2009/07/24/ were deaths_of 4 _women_a_matter_of_honour.html. Accessed 10 October 2010 .

Citizenship and Immigration Canada. 2009. Discover Canada: The Rights and Responsibilities of Citizenship. Ottawa: Citizenship and Immigration Canada. http://www.cic.gc.ca/english/resources/publications/discover/ index.asp?utm source $=$ slash-discovercanada\&utm medium $=$ shorturl\&utm campaign=generic. Accessed 13 January 2010.

Cohen, Tobi. 2012. Immigration marriage fraud crackdown raising concerns about domestic abuse. Vancouver Sun. http://www.vancouversun.com/ news/Immigration+marriage + fraud + crackdown + raising + concerns + abo ut/6919226/story.html. Accessed 26 May 2013.

Cohn, Martin. 1999. They kill their own in the name of honour. Toronto Star. August 1:1. 
Dale, Daniel. 2009. Shining a light on honour killings' dark corner. The Star http://www.thestar.com/article/671779. Accessed on 25 September 2010.

DiManno, Rosie. 2011. Cultural questions posed in Kingston quadruple-murder trial. Toronto Star. http://www.thestar.com/news/canada/article/1085652-dimanno-cultural-questions-posed-in-kingston-quadruple-murder-trial. Accessed 5 March 2012.

Farrukh, Saleem. 1999. The shame of "honour killings": In male-dominated Pakistan, some families get away with murdering or maiming women who try to escape abusive husbands. Vancouver Sun. September 17:A21.

Fournier, Pascale, Pascal McDougall, and Anna R. Dekker. 2012. Dishonour, provocation, and culture: Through the beholder's eye? Canadian Criminal Law Review 16:161-193.

General Assembly. 2001. 55/66 Resolution adopted by General Assembly. http:// www.un.org/ga/search/view doc.asp?symbol=A/RES/55/66\&Lang=E. Accessed 26 May 2013.

2002. Working towards the elimination of crimes against women committed in the name of honour: Report of the secretary general. http:// www.unhchr.ch/huridocda/huridoca.nsf/AllSymbols/985168F508EE79 9FC1256C52002AE5A9/\$File/N0246790.pdf. Accessed 27 May 2013.

Gill, Aisha. 2006. Patriarchal violence in the name of 'honour.' International Journal of Criminal Justice Sciences 1(1):1-12.

Grewal, Inderpal. 2013. Outsourcing patriarchy: Feminist encounters, transnational mediations and the crime of 'honour killings.' International Feminist Journal of Politics 15(1):1-19.

Haque, Eve. 2010. Homegrown, Muslim and other: Tolerance, secularism and the limits of multiculturalism. Social Identities 16(1):79-101.

Henry, Frances and Carol Tator. 2002. Discourses of Domination: Racial Bias in the Canadian English-Language Press. Toronto: University of Toronto Press.

Hesford, Wendy S. 2011. Spectacular Rhetorics: Human Rights Visions, Recognitions, Feminisms. Durham, NC: Duke University Press.

Hui, Ann. 2010. Confronting the 'honour killing' taboo. Globe and Mail. http:// www.theglobeandmail.com/news/toronto/confronting-the-honour-killing-taboo/article1387273/. Accessed 13 December 2011.

Human Rights Watch. 2009. Jordan: Tribunals no substitute for reforms on 'honour killings.' http://www.hrw.org/en/news/2009/09/01/jordan-tribunalsno-substitute-reforms-honor-killings. Accessed 12 September 2009.

Hussain, Mazna. 2006. 'Take my riches, give me justice': A contextual analysis of Pakistan's honour crime legislation. Harvard Journal of Law and Gender 29:223-246.
Husseini, Rana. 2009. Murder in the Name of Honour: The True Story of One Woman's Heroic Fight against an Unbelievable Crime. Oxford: One World.

Jafri, Beenash. 2012. National identity, transnational whiteness and the Canadian citizenship guide. Critical Race and Whiteness Studies 8:1-15.

Jamal, Amina. 2005. Transnational feminism as critical practice: A reading of feminist discourses in Pakistan. Meridians: Feminism, Race, Transnationalism 5(2):57-82.

Jehl, Douglas. 1999. A killing for honour: In some parts of the Arab world where a woman's chastity is everyone's business, the price of family honour is paid in a daughter's blood. Edmonton Journal. June 27:F1/Front.

Jiwani, Yasmin. 2006. Discourses of Denial: Mediations of Race, Gender, and Violence. Vancouver: University of British Columbia Press.

Jiwani, Yasmi and Homa Hoodfar. 2012. Should we call it 'honour killing'? The Gazette. http://mrcssi.com/wp-content/uploads/2011/10/The-Gazette.pdf.

Kaplan, Gerald. 2010. Honour killings in Canada: Even worse than we believe. Globe and Mail. http://www.theglobeandmail.com/news/politics/ second-reading/honour-killings-in-canada-even-worse-than-we-believe/ article1314263/. Accessed 26 May 2013.

Kay, Barbara. 2011. Communities must speak out against brutal traditions. $\mathrm{Na}$ tional Post. http://fullcomment.nationalpost.com/2011/01/26/barbarakay-communities-must-speak-out-against-brutal-traditions/. Accessed 11 February 2011.

Keung, Nicholas. 2011. Immigration down 25 per cent for this year: Fewer permanent visas were issued in the quarter of 2011. Toronto Star. July 18:A4.

2012. Wage cuts for foreign workers in Canada discriminatory, critics say. The Star. http://www.thestar.com/news/gta/2012/05/24/wage cuts for foreign workers in canada discriminatory critics say.html. Accessed 26 May 2013

Lazreg, Marnia. 2009. The triumphant discourse of global feminism: Should other women be known? Pp. 29-38 in Amal Amireh and Lisa Suhair Majaj, eds., Going Global: The Transnational Reception of Third World Women Writers. New York: Garland Publishing.

McKay, Ian and Jamie Swift. 2012. Warrior Nation: Rebranding Canada in an Age of Anxiety. Toronto: Between the Lines.

Mahtani, Minelle. 2008. Racializing the audience: Immigrant perceptions of mainstream English-language news. Canadian Journal of Communication 33(4):639-660.

2009. The racialized geographies of news consumption and production Contaminated memories and racialized silences. GeoJournal 74:257264. 
Papp, Aruna. 2010. Culturally-driven violence against women: A growing problem in Canada's immigrant communities. Frontier Center for Public Policy Series 92:1-20.

n.d. Trainings Delivered - 2012-2013. http://www.preventhonorbasedviolence.com/4 events.html. Accessed 28 May 2013.

Papp, Aruna and Barbara Kay. 2011. Unworthy Creature: A Punjabi Daughter's Memoir of Honour, Shame and Love. St. Catherine's, ON: Freedom Press.

Proudfoot, Shannon. 2009. Up to a dozen 'honour killings' in Canada in past decade. Vancouver Sun. July 24: B.1

Puar, Jasbir. 2007. Terrorist Assemblages: Homonationalism in Queer Times. Durham, NC: Duke University Press.

Razack, Sherene. 1998. Looking White People in the Eye: Gender, Race, and Culture in Courtrooms and Classrooms. Toronto: University of Toronto Press.

2003. A violent culture or culturalized violence? Feminist narratives of sexual violence against South Asian women. Studies in Practical Philosophy 3(1):80-104.

2008. Casting Out: The Eviction of Muslims from Western Law and Politics. Toronto: University of Toronto Press.

2012. Memorializing colonial power: The death of Paul Frank. Law and Social Inquiry 37(4):908-932.

Salutin, Rick. 2012. Beware the simple explanations after the Shafia murder verdicts. Toronto Star. http://www.thestar.com/opinion/editorialopinion/2012/02/02/beware the simple explanations_after_shafia murder verdicts.html. Accessed 28 May 2013.

Shalhoub-Kevorkian, Nadera. 2002. Reexamining femicide: Breaking the silence and crossing 'scientific' borders. Signs: Journal of Women in Culture and Society 22(2):582-608.

Star Editorials. 2011. The Conservative record: Immigrants see a harsher Canada. The Star. http://www.thestar.com/opinion/editorials/2011/02/19/ the conservative record immigrants see a harsher canada.html. Accessed 26 May 2013

Status of Women Canada. 2010a. Minister Ambrose calls for community action to help end 'honour crimes'. http://www.ronaambrose.com/media /inthe-news2/breaking-the-silence-on-acts-of-violence-committed-in-thename-of-honour. Accessed 26 May 2013.

2010b. Speaking notes for the Honourable Rona Ambrose. http://www. ronaambrose.com/media/in-the-news $2 /$ breaking-the-silence-on-actsof-violence-committed-in-the-name-of-honour. Accessed on 10 August 2010.

2012. Breaking the silence on acts of violence committed in the name of honour. http://www.swc-cfc.gc.ca/med/news-nouvelles/2012/0515-eng. html. Accessed on 26 May 2013.

Thobani, Sunera. 2007. Exalted Subjects: Studies in the Making of Race and $\mathrm{Na}$ tion in Canada. Toronto: University of Toronto Press.
Turgut, Pelin. 1998. For the family's honour: Any defilement of a young woman's virtue, or suspicion of an illicit liaison, can mean death at her family's hands. The Gazette. Montreal, QC. May 4:B6.

United Nations Entity for Gender Equality and the Empowerment of Women. n.d. Defining "honour" crimes and "honour" killings. End Violence Now http://www.endvawnow.org/en/articles/731-defining-honourcrimes-andhonour-killings.html. Accessed 26 May 2013.

Volpp, Leti. 2002. On culture, difference, and domestic violence. Journal of Gender, Social Policy, and the Law 11(2):393-399.

Warrick, Catherine. 2005. The vanishing victim: Criminal law and gender in Jordan. Law and Society 39(2):315-348.

Zine, Jasmin. 2009. Unsettling the nation: Gender, race, and Muslim cultural politics in Canada. Studies in Ethnicity and Nationalism 9(1):146-163.

Dana M. Olwan is Assistant Professor of Women's and Gender Studies at Syracuse University. In 2011-2012, she was the Junior Ruth Wynn Woodward Chair at the Department of Gender, Sexuality, and Women's Studies at Simon Fraser University. She writes on gendered and sexual violence, feminist solidarities, and anticolonial struggles from Canada to Palestine.

dmolwan@syr.edu 
